\title{
He Tātai Whenua: Environmental Genealogies
}

\author{
Margaret Forster ${ }^{\dagger}$ \\ Te Pūtahi-a-Toi-School of Māori Knowledge, Massey University, Palmerston North 4442, New Zealand; \\ m.e.forster@massey.ac.nz; Tel.: +64-6-350-5701 \\ † Rongomaiwāhine and Ngāti Kahungunu.
}

Received: 27 May 2019; Accepted: 16 July 2019; Published: 19 July 2019

check for updates

\begin{abstract}
Whakapapa, an indigenous form of genealogy of the Māori people of Aotearoa New Zealand, is a powerful tool for understanding social phenomena. In this paper, the environmental histories of Aotearoa New Zealand are converted to whakapapa/genealogical sequences and kōrero tuku iho/narratives derived from whakapapa, to demonstrate this explanatory power. It is argued that whakapapa is much more than a method for mapping kinship relationships. Whakapapa enables vast amounts of information to be collated and analysed, to reveal a multitude of narratives. It also facilitates a critique of indigenous rights issues, revealing Māori agendas for environmental management. Therefore, the whakapapa sequences and narratives created as part of this paper provide an understanding that is not restricted to the grand narrative or the past as whakapapa is never-ending, dynamic, fluid and future-focused.
\end{abstract}

Keywords: whakapapa; genealogical sequences; genealogical narratives; environmental management

Whakapapa is a distinctly Māori way of organising and understanding the world through genealogies. It is enacted daily as Māori people cite whakapapa to acknowledge relationships with the land and each other. There are examples of the use of korero tuku iho/genealogical narratives or narratives derived from whakapapa, to explain a range of phenomena including the origin of the first family, humanity, knowledge, fire and death (see for example (Mikaere 2003)). Although whakapapa is a powerful analytical tool it is more common today for explanations about new phenomena to be drawn from core cultural concepts. Well-known examples include Professor Sir Mason Durie's te whare tapa whā $(1994)^{1}$ and Rangimarie Rose Pere's te wheke ${ }^{2}$ (1991) conceptualisations of Māori health. However, explanations drawn from cultural concepts are limited. Therefore, this paper provides an example of using whakapapa sequences in association with genealogical narratives to understand environmental management in Aotearoa New Zealand. The intent is to demonstrate the power of whakapapa for understanding trends and contemporary issues and determining future pathways, to encourage others to use Māori ways of knowing such as whakapapa.

\section{Explanatory Tools for Understanding the World}

Te Ahukāramu Charles Royal $(1998$, p. 2) points out that whakapapa was used in the past to "generate explanations for many things in the phenomenal world", the world that we experience through our senses like natural resources, seasons, and fire to name just a few. He argues that

1 For those readers unfamilar with this model te whare tapa wha is a tool for conceptualising wellbeing from a Māori perspective (Durie 1994; Rochford 2004) based on the metaphor of a four sided house. It emphasises that wellbeing is dependent on four interconnected cultural concepts or dimensions-taha wairua/the spiritual, taha hinengaro/the mental, taha whānau/the family and, taha tinana/the phyiscal. This model was developed to contest the dominant medical model of health that tends to focus on illness and physical dimensions.

2 Te wheke (Pere 1991) is another Māori health model with an emphasis on whānau/family. This model is depicted by te wheke/the octopus. The head represents the family and each of the tentacles a distinct cultural health concept. 
whakapapa is a methodology for creating mātauranga Māori, knowledge derived from a Māori view of the world, from ancestral knowledge and practices to regulate human behaviour. Whakapapa could also be a useful and relevant methodology for explaining contemporary situations and experiences (Royal 1998). Several Māori scholars agree. Joe Te Rito explored the more frequently understood expression of whakapapa as genealogy and genealogical narrative demonstrating the continued relevance of whakapapa as the basis of tracing Māori views of reality and for informing contemporary identity and wellbeing (Te Rito 2007). James Graham (2009a) acknowledged that whakapapa is the "most fundamental aspect of the way Māori think about and come to know the world" (p. 2) and is a "means and way to acquire new knowledge" (p. 2). Through his research on the connection between Māori advancement and Māori boarding schools (Graham 2009b) he demonstrated how whakapapa can be deployed as a research framework to legitimise Māori approaches to research and create a Māori knowledge base. In this context, whakapapa is used to guide, contest and validate the research process.

Probably the most common way that whakapapa is deployed in research is through whakapapa/genealogical narratives. This approach maps the origin and nature of phenomena by reviewing Māori sources of information such as whakapapa, pūrākau/narratives, whakataukī/sayings, waiata/songs and mātauranga/knowledge. These sources are reconstituted in relation to Māori lived experiences and Māori political agendas to create new understandings and tikanga/actions. A well-known example is Linda Tuhiwai Smith's (1999) critique of Western research and the emergence of kaupapa Māori research as a means of disrupting Western control over indigenous peoples, our culture, knowledge and futures. Her work provides a genealogical narrative of marginalisation, resistance and empowerment through reaffirmation of indigenous knowledge, ways of knowing and associated practices.

In the environmental field, whakapapa is widely acknowledged as a template for establishing environmental order and acknowledging place-specific relationships (Haami and Roberts 2002). For example, as a form of taxonomy or classification system, whakapapa can map origin and relationships (Haami and Roberts 2002). Whakapapa is closely linked to genealogical narratives that can be used to guide interactions with specific natural resources and ecosystems such as the cultivation of kumara (Haami and Roberts 2002). In contemporary contexts whakapapa and genealogical narratives are being used to determine core values to guide natural resource use and management (Kawharu 2000; Roberts et al. 1995), monitor environmental health (Awatere and Harmsworth 2014; Tipa and Teirney 2003) and address pressing environmental issues such as environmental degradation (Morgan 2004) and climate change (Carter 2019; King et al. 2018).

Despite the presence and considerable influence of these works, there are very few examples of whakapapa sequences that explain contemporary phenomena. Whakapapa sequences are the visual representations of whakapapa as depicted in Figure 1 where a relationship between entity A and B creates a new entity $C$.

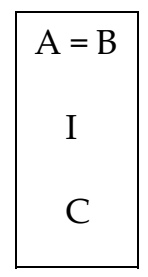

Figure 1. A basic whakapapa sequence.

Hone Sadler's work is one exception. He created several whakapapa sequences for analysing the impact of Te Tiriti o Waitangi ${ }^{3}$ on what he refers to as "Māori social and cultural fabric"

3 Treaty of Waitangi; A treaty negotiating Māori and British sovereignty in Aotearoa New Zealand. 
(Sadler 2007, p. 40) including the impact of alcohol (p. 42) and the emergence of social issues such as unemployment, family violence and abuse, and mental health issues (pp. 43-44). Sadler's work is one of the few published examples of the creation of whakapapa sequences for understanding and analysing contemporary phenomena.

The use of genealogy to explain social phenomena is not unique to Māori. One tradition that complements the analysis provided in this paper is the Foucauldian genealogy approach to governmentality (Bevir 2010; Rose et al. 2006). Governmentality critiques are concerned with political power, truths and governance with a strong focus on investigating possibilities of thinking and acting in new ways. In relation to environmental policy in Aotearoa New Zealand, such a critique involves mapping the emergence of specific ways of thinking about the environment, and considering why and how these truths impact on environmental management and, in particular, Māori environmental agendas. Elsewhere, I have used a genealogy approach to governmentality to create a series of environmental histories that show why and how a Māori environmental agenda has struggled to emerge beside the dominant exploitative economy agenda that prioritises the primary industries (Forster 2013b). However, continued contests from Māori to disrupt this status quo has created new ways of thinking and acting by embedding kaitiakitanga, or a Māori environmental ethic that prioritises sustainable resource use into the Aotearoa New Zealand environmental management space (Forster 2012, 2014, 2016). This paper builds on this work by converting these environmental narratives into whakapapa sequences to demonstrate how whakapapa could be used to explain the phenomena of environmental management. The utility of this approach is tested through application to specific environmental practices associated with wetland drainage and restoration.

This approach to understanding the social phenomena of environmental management is attractive for several reasons. Firstly, it privileges Mãori ways of knowing and acting such as an emphasis on whakapapa in the form of relationships and interactions. Secondly, it enables a focus on power and indigenous rights and in particular Māori activism to realise a range of Māori political agendas. Finally, whakapapa is able to collate, process and represent small to vast amounts of information. This versatility is advantageous for exploring both specific and series of events.

Whakapapa, therefore, is more than a way of mapping kinship relationships. It is a system of thought based on an interrelatedness that establishes connections with ancestors and the environment and creates culturally appropriate ways of acting. These actions are codified through a set of inherited obligations and responsibilities to ancestors, place and future generations:

In te ao Māori, all of the myriad elements of creation-the living and the dead, the animate and inanimate-are seen as alive and inter-related. All are infused with mauri (that is, a living essence or spirit) and all are related through whakapapa... The people of a place are related to its mountains, rivers and species of plant and animal, and regard them in personal terms. Every species, every place, every type of rock and stone, every person (living or dead), every god, and every other element of creation is united through this web of common descent...

This system of thought provides intricate descriptions of the many parts of the environment and how they relate to each other. It asserts hierarchies of right and obligation among them... These rights and obligations are encompassed in another core value-kaitiakitanga. Kaitiakitanga is the obligation, arising from the kin relationship, to nurture or care for a person or thing. It has a spiritual aspect, encompassing not only an obligation to care for and nurture not only physical well-being but also mauri [life force] ...

In the human realm, those who have mana [authority] ... must exercise it in accordance with the values of kaitiakitanga - to act unselfishly, with right mind and heart, and with proper procedure. Mana and kaitiakitanga go together as right and responsibility, and that kaitiakitanga responsibility can be understood not only as a cultural principle but as a system of law. (Waitangi Tribunal 2011, p. 23) 
Enacting whakapapa or performing kinship obligations and responsibilities is intricately linked to tribal sovereignty. Conversely, when whakapapa is absent within day-to-day activities then connections to ancestors and the environment weaken. When this notion is applied to understanding social phenomena whakapapa can be used to trace and critique origin, complex connections and interactions-although is much more than just a chronological history of events. It can make explicit dominant imperatives whilst also making visible those imperatives that have failed to gain traction at specific junctures of time thereby inviting consideration of whether we can think or act differently.

\section{Environmental Histories of Aotearoa New Zealand}

There are two dominant and at times contested environmental traditions in Aotearoa New Zealand. One is derived from the Māori presence in this country and the other was introduced as part of the British Colonial Project (Pawson and Brooking 2013). Whakapapa can be used to map how these traditions interact and explain trends in environmental management. Three distinct but interconnected whakapapa-Te Ao Māori/the Māori world, Te Ao Hurihuri/the changing world and Te Ao Tautohe/the contested world—will be described here to provide a synthesis of Aotearoa New Zealand environmental histories.

\subsection{Te Ao Māori/the Māori World}

Every culture has its traditions about how the world was created. Māori have many of them, but the most important stories are those that tell how darkness became light, nothing became something, earth and sky were separated, and nature evolved. (Royal 2005)

Figure 2 is a visual representation of a Māori view of the world-Te Kore-Te Pō-Te Ao Mārama (Royal 2003). This whakapapa sequence can also be represented by a genealogical narrative associated with the union of Ranginui and Papatūānuku, ${ }^{4}$ the Sky Father and Earth Mother, the source of all life (Mikaere 2003). Emerging from these whakapapa sequences and narratives are a series of ideologies and behaviours, actions or practices (Mead 2003; Roberts et al. 1995). These whakapapa sequences, therefore, emphasise the link between genealogy, Māori thought and actions. To understand these links a more detailed exploration of the various elements in Figure 2 is needed.

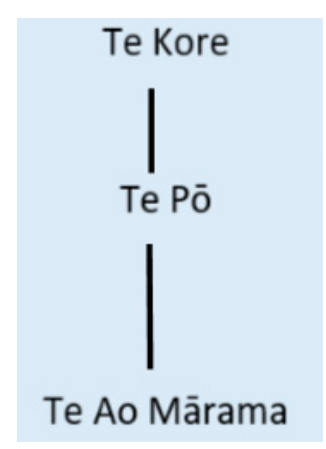

Figure 2. Whakapapa sequence representing Te Ao Māori/the Māori world.

Te Kore-Te Pō-Te Ao Mārama is a well-known whakapapa sequence revealing "how darkness became light, nothing became something" (Royal 2005; part of the quote at the start of this section). This is the condensed version with Māori Marsden indicating that in the full version from Ngā Puhi tribe there are 12 Te Kore stages and 12 Te Pō stages (Royal 2003, p. 19). While each of the stages are important in their own right, the whakapapa sequence emphasises a movement from a period of

4 The genealogical narratives provided here are based on the author's own tribal traditions-those of the Ngāti Kahungunu people. It is important to note that other tribes have their own traditions that can differ from the one described here. 
darkness to a period of potential where shape and form begin to emerge and eventually to a period of light where the world as a physical entity emerges. This whakapapa sequence finds physical expression within the wharenui/meeting house with the inside of the building representing Te Kore, the entrance is Te Pō and when one crosses the threshold and walks outside they emerge into Te Ao Mārama, the world of light. The whakapapa sequence is also encapsulated in the well-known kōrero tuku iho/genealogical narrative of the primordial parents Ranginui and Papatūānuku (Figure 3) (Mikaere 2003) and how "earth and sky were separated, and nature evolved" (Royal 2005; part of the quote at the start of this section):

In the Māori story of creation, the earth and sky came together and gave birth to some 70 children, who eventually thrust apart their parents and populated the world. Each of the children became the god of a particular domain of the natural world. Their children and grandchildren then became ancestors in that domain. For example, Tangaroa, god of the sea, had a son called Punga. Punga then had two children: Ikatere, who became the ancestor of the fish of the sea, and Tūtewehiwehi, who became the ancestor of the fish and amphibious lizards of inland waterways. (Royal 2007)

The children of Ranginui and Papatūānuku were born into Te Pō, the dark world of potential and when they thrust apart their parents Te Ao Mārama the world of light was created. It is in the world of light that natural resources and humanity emerged. Figure 3 is a whakapapa sequence depicting the origin of natural resources and humanity.

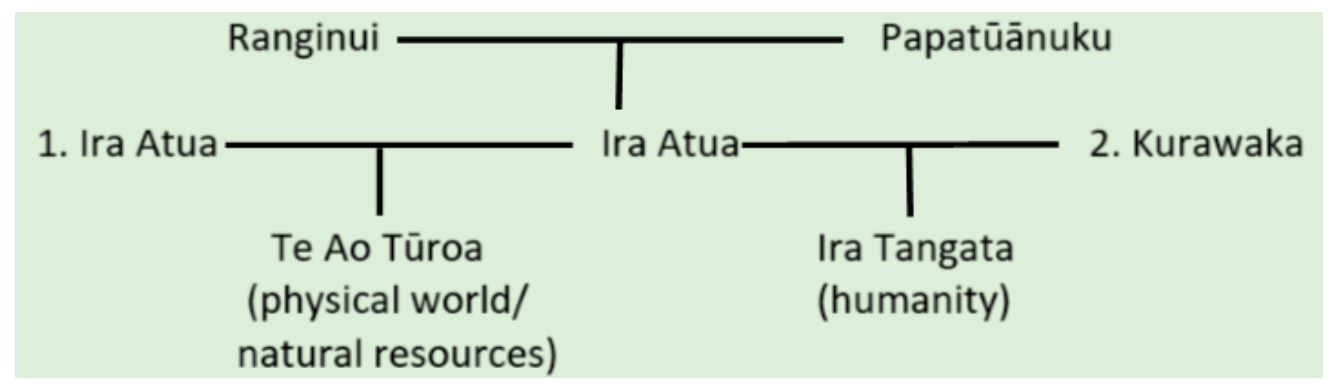

Figure 3. Whakapapa sequence representing the genealogical narrative of the primordial family.

In Figure 3, the children of Ranginui and Papatūānuku are referred to as the ira atua/ancestral life principles. Unions between the various ira atua produced Te Ao Tūroa, the natural world and the natural resources. Once this world was formed the ira atua turned to the task of creating the ira tangata, humanity.

The children of Ranginui and Papatūānuku had only talked of life ... They had not experienced it for themselves, not in the physical forms that tormented their imaginations... [but] it was the human form that eluded ... Papatūānuku waited until she knew the time was right, then led Tāne to her sacred place, to Kurawaka. This was where he fashioned me [Hineahuone] from the red clay he found there. I was the first. The first to breathe, to touch, to feel, to hold, to know, to experience everything of the newly created world. (Excerpts from the poem Hineahuone by Wiremu (Grace n.d.))

Hineahuone is the mother of humanity. She was formed from the Earth and imbued with the essence of the ira atua (Mikaere 2003). This is the origin of one of the names of the Māori people-tangata whenua meaning people of or from the Earth. Hineahuone gave birth to the first human form-Hinetitama (Mikaere 2003) creating a kinship relationship with the spiritual world as represented by Ranginui, Papatūānuku and their children and natural resources (Roberts et al. 1995; Royal 2003).

These whakapapa sequences and genealogical narratives provide a framework for understanding Te Ao Māori, the Māori world. Key elements of this world include a kinship connection between 
the spiritual world, the natural world, and people. Another way of expressing these connections is through the concepts of mana atua, mana whenua (Durie 1998; Warren et al. 2017) and mana tupuna. These concepts acknowledge the importance of mana and mauri (authority and life force) for understanding how the spiritual world, natural resources and people interact (Figure 4), thereby shaping the way we think and act (Kawharu 2000; Roberts et al. 1995).

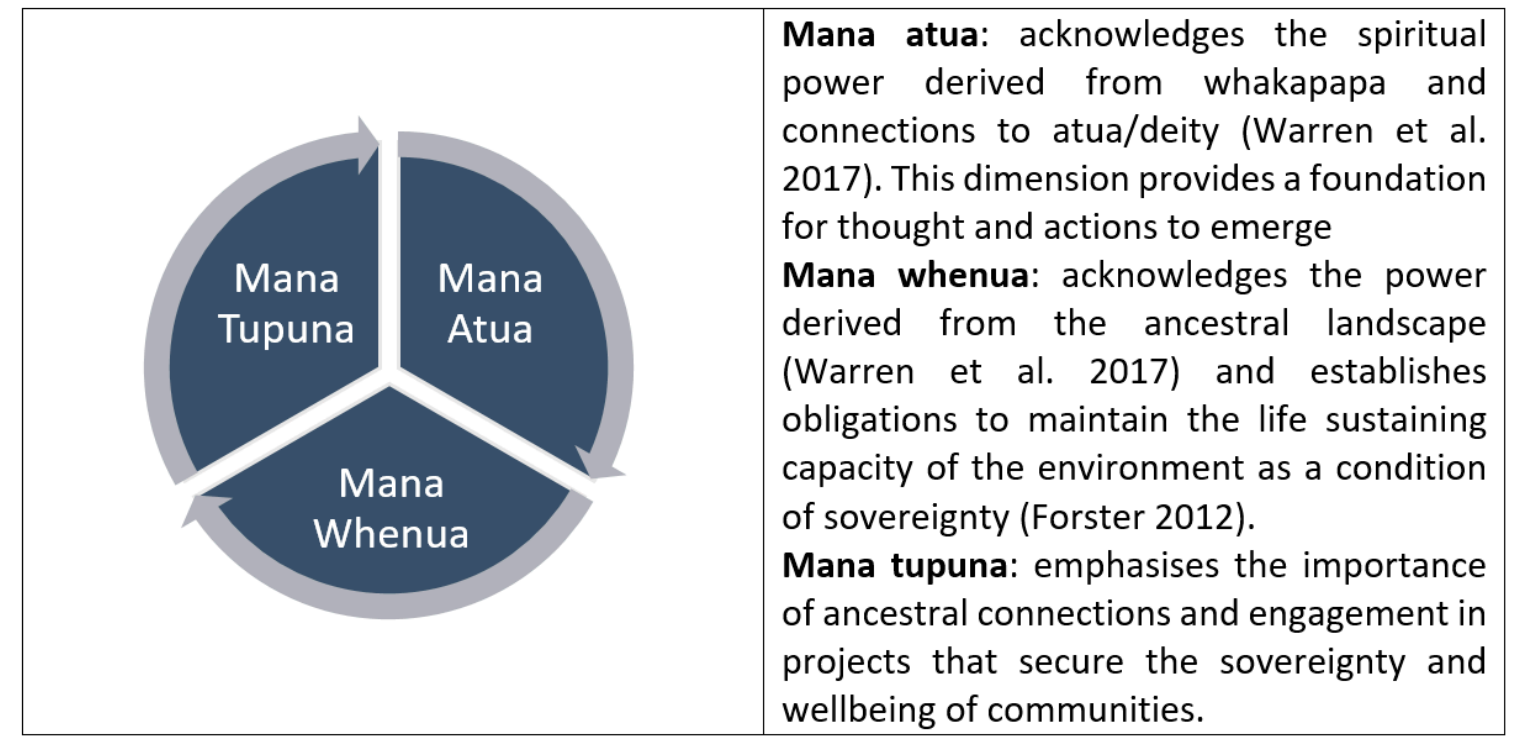

Figure 4. The role of mana and mauri in governing environmental conduct.

The relationships, obligations and responsibilities that emerge from an ideology based on mana and mauri established norms and values that regulate human-environmental activities (Mead 2003; Roberts et al. 1995; Royal 2003). Māori Marsden referred to these activities as tikanga tiaki/guardianship customs (Royal 2003). In relation to the environment, the intent of these ideologies and practices was to maintain the life-sustaining capacity of the environment for future generations in accordance with custom. A whakapapa sequence representing these relationships and obligations is provided in Figure 5.

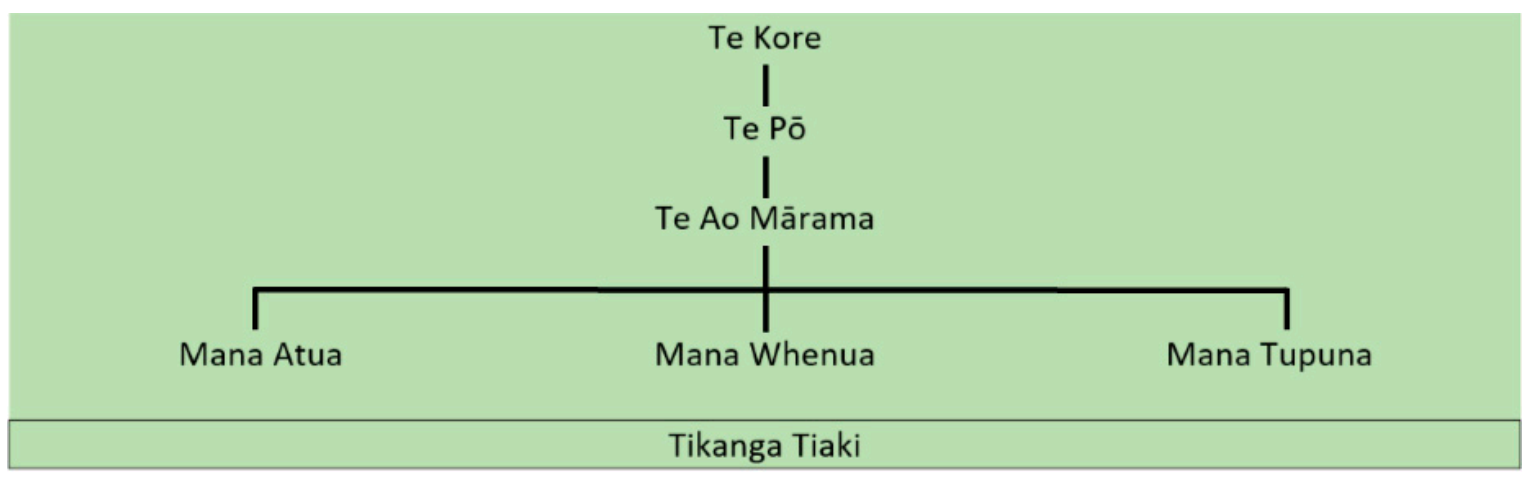

Figure 5. A whakapapa sequence indicating connections between a Māori view of the world, Māori thought and practices.

Māori actively managed the ancestral landscape to maximise survival of the community (Pawson and Brooking 2013). Burning was used to clear areas for the purpose of hunting and gardening. Tikanga tiaki such as rahui/restrictions and practices associated with mahi mara/gardening and mahinga kai/collection of wild foods emerged to regulate the harvesting of food and ensure food security (Best 1976, 1977a, 1977b). Survival was based on maintaining a delicate balance between mana whenua 
and mana tangata. This balance was disrupted by colonial settlement (Walker 1990) that entrenched a new environmental ethic that valued exploitative economies (Pawson and Brooking 2011).

\subsection{Te Ao Hurihuri/the Changing World}

An overriding feature of New Zealand's environmental histories has been the use of land and water for successive waves of resource exploitation, for which reason this remains a country heavily dependent on a narrow range of primary exports. In the nineteenth century, wool, wheat and timber booms followed sealing and goldmining; in the twentieth century, the preoccupation was with the extraction of maximum value from grass-based commodities. Such resource 'quarrying', of living 'off' rather than 'with' the land, has been framed through systems of law, surveying, cartography and metrology... reveal[ing] how fragile and unstable are the land and waters so measured and appropriated... acquisition of intimate environmental knowledges through the senses of Māori has not always been replicated among Pākehā. The assumption of the colonial project of improvement has been that of an essentially benign, if not fixed or knowable, environmental stage, which is why the project has in its turn been portrayed as 'fraught and vulnerable'. (Pawson and Brooking 2011, p. 331)

The British colonial project introduced new ideas, technologies and peoples to the Aotearoa New Zealand landscape. An abrupt change to authority over the environment emerged and Māori communities experienced widespread disruption to Te Ao Māori (Forster 2013a; Walker 1990). Figure 6 is a whakapapa sequence that demonstrates the interaction between the two dominant and contested environmental traditions—one derived from Te Ao Māori (a repeat of Figure 5), the other introduced by the British colonial project.

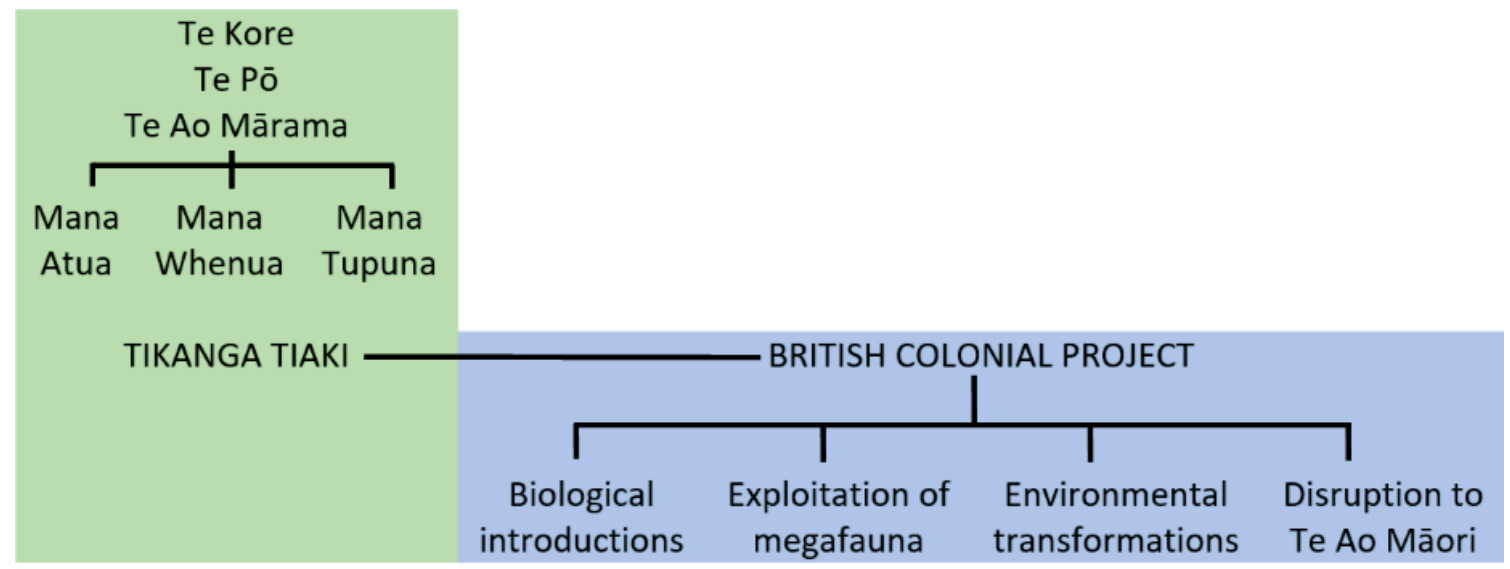

Figure 6. A whakapapa sequence depicting the interaction between Te Ao Māori and Te Ao Hurihuri.

This whakapapa sequence is a narrative of domination and suppression. As settler power was consolidated through parliament, legislation, land ownership and immigration (Boast 1999; Hayward and Wheen 2004) environmental policy normalised settler and suppressed Māori agenda and aspirations (Pawson and Brooking 2011; Forster 2013a). Four key dimensions of change that underpinned the exploitative economies occurred-biological changes (Young 2004), exploitation of megafauna (Young 2004), environmental transformations (these are all environmental changes) (Pawson and Brooking 2011) and disruption to Te Ao Māori (sociopolitical changes) (Walker 1990). Each of these dimensions has its own histories and ideologies that underpinned environmental policy, leaving behind a legacy of resource depletion and environmental degradation:

The effects of Māori hunting, fire and horticulture were extensive. But they were less dramatic than 200 years of Pākehā transformations, initiated as part of the European imperial drive to incorporate new territories into the capitalist world economy... There have 
been contests for land between Māori and Pākehā, vigorous throughout the nineteenth century and not forgotten by Māori since, and environmental interventions resulting in resource destruction, soil erosion and the spread of unwanted, and costly, pests and weeds. (Pawson and Brooking 2011, p. 17)

However, Māori and supporters of a conservation agenda have continuously contested the emphasis on exploitative economies (Forster 2014, 2016; Young 2004). By the 1950s, a global movement for sustainability (McClean and Smith 2001) was also beginning to influence the direction of Aotearoa New Zealand's environmental policy (Memon 1995); change was imminent.

\subsection{Te Ao Tautohe/the Contested World}

Aotearoa New Zealand has a long history of Māori contesting the Government's agenda, including the British Crown's right to absolute sovereignty and consequently governance (Belgrave et al. 2004; Tawhai and Gray-Sharp 2011). Māori have engaged in a range of activism activities over a long period of time (Harris 2004; Taonui 2012; Walker 1984) challenging the state's authority and various agendas particularly the introduction of individualised land ownership and the elimination of collective tribal ownership. Māori have consistently and forcibly argued that under the terms of Te Tiriti o Waitangi, Aotearoa New Zealand was founded on Māori and Crown partnership and prosperity for all. Therefore, Māori interests also need to be a feature of governance.

In relation to the environment, Māori aspire to engage in enterprise (Petrie 2006) as well as maintaining access to customary food sources. During the Te Ao Hurihuri period concerns were quickly raised as access to forest and wetlands resources began to diminish; customary lifestyles transformed overnight rendering a reliance on the colonial economy.

Māori were not the only ones to raise concerns over the impact of environmental change on the wilderness and native flora and fauna. There is a long history of an active and vocal conservation movement in Aotearoa New Zealand (Young 2004). By the 1950s, there was also growing concern worldwide over environmental degradation and resource depletion that mobilised international level political pressure and United Nations instruments for supporting a global sustainability agenda. In Aotearoa New Zealand, Māori leveraged this pressure to demand the recognition of Māori environmental rights. Today, there are several legislative and policy instruments that recognise Māori environmental aspirations under the umbrella of kaitiakitanga (Hayward 2003). This grand narrative is captured in Figure 7 (yellow segment).

The green segment in Figure 7 is a collapsed or short version of the Te Ao Māori whakapapa sequence from Figure 5. The blue segment is a collapsed version of Te Ao Hurihuri whakapapa sequence from Figure 6; the British colonial project introduced considerable environmental change and disruption to Te Ao Māori. The new whakapapa sequence (yellow segment) represents the relationship between Māori activism and a global environmental agenda demanding a change to the way the environment and natural resources were managed. In an Aotearoa New Zealand context an emphasis on kaitiakitanga and environmental sustainability has emerged. It is important to note that kaitiakitanga is a contemporary form of tikanga tiaki-which is why it appears in both the blue and yellow segments of Figure 7. Some examples of contemporary resource management practices include the following: legislative instruments like the Resource Management Act 1991 that ensures sustainability is a key driver of resource management decisions; collaborative projects like the national Fresh Start for Fresh Water project that sets the direction of Aotearoa New Zealand water, and; land policy and mana whenua projects that revitalise and/or restore areas of tribal significance to meet obligations to ancestors and future generations.

Te Ao Tautohe whakapapa sequences emphasise the importance of contests for thinking and acting in new ways. To demonstrate how contests can enable change a brief wetland story is provided. 


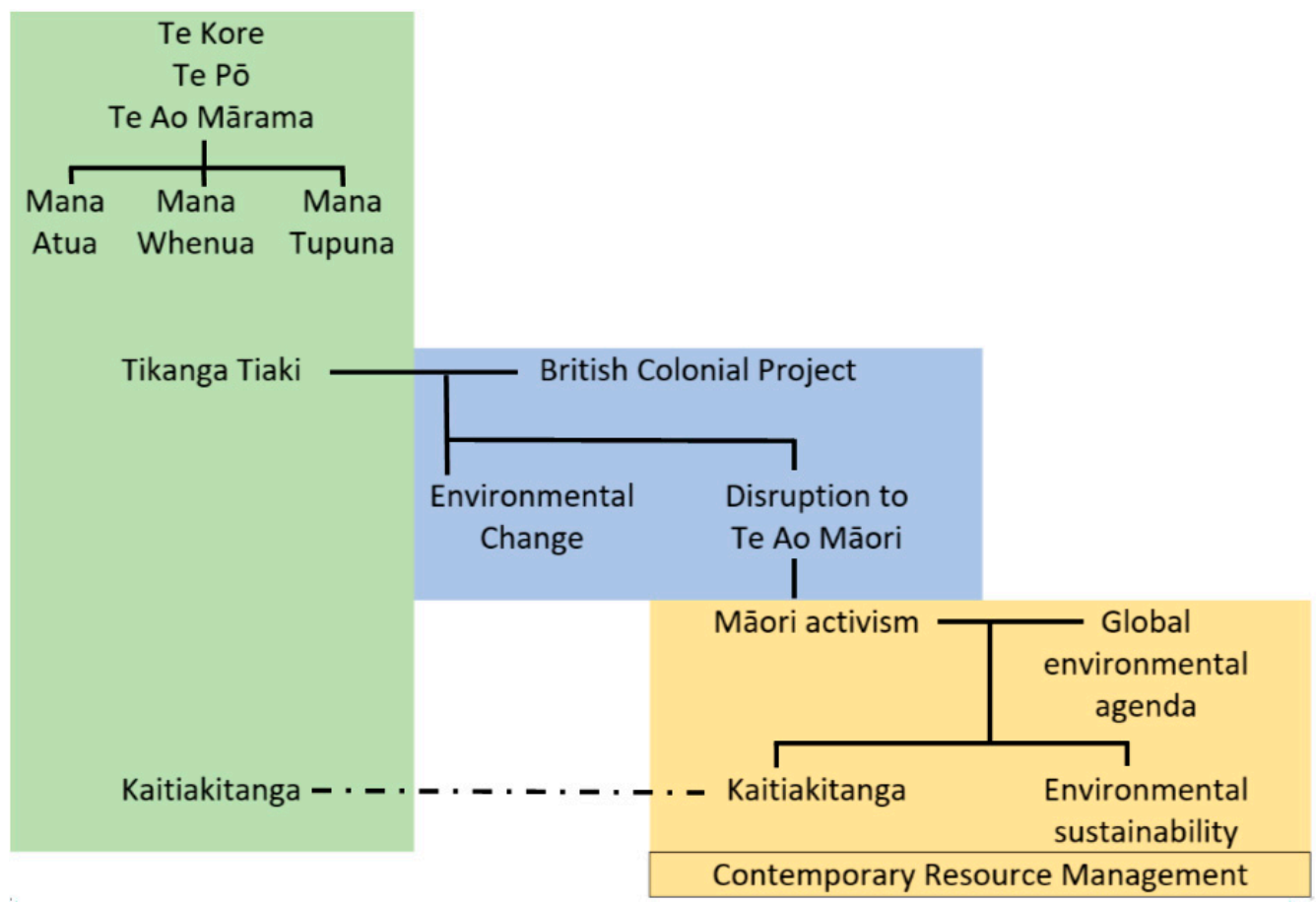

Figure 7. A whakapapa sequence that collates together all three environmental 'era'-Te Ao Māori (green segment), Te Ao Hurihuri (blue segment) and Te Ao Tautohe (yellow segment).

\subsection{A Wetland Story}

This wetland story is told through the three distinct but interconnected whakapapa sequences created for this paper (Figure 7). A Te Ao Māori/Māori world view is articulated in this letter written by elder Huki Solomon:

In the days of our forefathers and to the present day, the great lake has been a major source of food... The tangata whenua [local indigenous people] of Whakaki [derived] a total way of life from this lagoon and its tributaries. Their ancestors are buried... around the perimeters of the lagoons. The spiritual connections are strongly bonded between the land, lagoons and people. The heritage bonds give the tangata whenua their pride, their mana [power and prestige] and their spiritual culture.

This has now changed drastically due to the ecosystem being muddled with by engineers... The food source which the people of Whakaki relied on... has now almost disappeared... The river... has now silted up.

In these changing times where a natural order of nature is fast disappearing we as kai tiaki (Trustees) of the environment should endeavour to maintain all natural resources. This is to ensure that future generations can grow up with a heritage that is a vital part of being Māori. (Letter written 25 May 1992 from Huki Solomon to the Parliamentary Commission for the Environment, Helen Hughes)

The letter points out that Whakakī Lake and wetland system in the Hawke's Bay region of the North Island, New Zealand is a significant resource in the tribal territory of my ancestors. Survival as a people was dependent on this resource and the lake and associated natural resources are intricately linked to our mana and tribal identity. This letter provides examples of mana atua/spiritual power, mana whenua/power derived from ancestral landscape and mana tupuna/ancestral connections. For example, mana atua connections are referenced by the phrase "heritage bonds" and mana whenua is expressed through the desire to influence contemporary resource management decision-making. The intent was 
to ensure that mana tupuna responsibilities are maintained, particularly nurturing the wellbeing of natural resources and ensuring the survival of "heritage" for future generations of our people.

In this regard, the letter is an example of Māori activism. It is a response to a succession of environmental changes, introduced during Te Ao Hurihuri/the changing world, that have compromised the authority of the local indigenous people to interact with a lake and wetland system according to custom (referred to in the whakapapa sequences as tikanga tiaki).

Environmental transformations were one of the products of the British Colonial Project. Across Aotearoa New Zealand there was extensive drainage of wetlands for agricultural purposes mainly cropping and pastoralisation, or as Brad Coombes and Stephanie Hill (Coombes and Hill 2005) so eloquently expressed it "Fishing for land under water". It is estimated that $85-90 \%$ of Aotearoa New Zealand's freshwater wetlands have been lost (Taylor 1997). The remnant wetlands are fragmented and highly modified and today restoring these ecosystems is a high priority.

The restoration agenda has emerged in Te Ao Tautohe/the contested world. Māori activism and a global environmental agenda challenge the continuance of resource use that leads to resource depletion and environmental degradation. This reasoning is supported in an Aotearoa New Zealand context by a national sustainable management agenda for natural resources (Memon 1995) that includes recognition of Māori environmental interests particularly the practice of kaitiakitanga. From a Māori perspective, restoration acknowledges Māori rights and responsibilities and strengthens ancestral connections and kaitiakitanga practices. From an environmental sustainability perspective restoration addresses issues with ecological functioning (i.e., regulation of water table) and a decline in biodiversity.

For the local people of Whakaki wetland restoration has restored much more than the local wetland ecology. Restoration began in 1994 with hydrological changes and a replanting programme (Forster 2013b). The project was the first hapū-based wetland restoration programme enabling the local hapu/subtribe to exercise their tribal authority and sovereignty through a series of partnerships with government agencies and environmental organisations. Over the years, various monitoring programmes have also been initiated to determine the health and vitality of local flora and fauna. This knowledge has been used to develop new projects that enhance the wellbeing of the lake and associated resources. These efforts by the local Māori community have received international (Ramsar) and national-level recognition.

This project is an example of kaitiakitanga. Kaitiakitanga is a contemporary expression of tikanga tiaki. It is a word used to encompass Māori environmental stewardship. It is closely linked to ancestral obligations of tribes to "nurture and care" for the environment in their ancestral territory (Waitangi Tribunal 2011, p. 5) for future generations.

This wetland story provides an example of the importance of contests for challenging the status quo and introducing change. The wetland story emerges from the whakapapa sequences associated with Te Ao Māori, Te Ao Hurihuri and Te Ao Tautohe demonstrating the explanatory power of whakapapa.

\section{Discussion and Conclusions}

Whakapapa is a powerful tool that was used to explain new phenomena. Today, however, the use and application of whakapapa in this context is arguably less prevalent and limited to recording genealogy. The intent of this paper is to demonstrate how new whakapapa sequences can be created and challenge others to use whakapapa sequences to critique new issues.

Whakapapa sequences to explain the environmental histories of Aotearoa New Zealand were created. Unlike conventional whakapapa that identify people or natural resources the whakapapa sequences created also reference ideologies, events and activities to demonstrate the interconnectedness of thinking and acting in specific ways.

Three whakapapa sequences were created-Te Ao Māori (Figure 5), Te Ao Hurihuri (Figure 6) and Te Ao Tautohe (Figure 7). Te Ao Māori whakapapa sequence brings together elements of the physical world (te ao tūroa), the intellectual (Te Pō-Te Kore-Te Ao Mārama) and the cultural (mana atua, mana whenua, mana tupuna) to explain how Māori conceptualise the world and develop practices for 
regulating interactions with the environment (tikanga tiaki). Te Ao Hurihuri marks the introduction of a new environmental thinking to Aotearoa New Zealand through the British Colonial Project. This new intellectual tradition introduced extensive change to the landscape (environmental changes) and disruption to Te Ao Māori. Te Ao Tautohe whakapapa sequence emphasises contests between Te Ao Māori and the British Colonial Project. In this whakapapa sequence, kaitiakitanga emerges as a modern, contemporary environmental ethic that has been used to leverage global support for environmental sustainability to secure Māori environmental agenda and aspirations.

The whakapapa sequences condense vast amounts of information. One of the strengths of this approach for the narration of histories is that each element of the whakapapa sequences can be collapsed to summarise or expanded to explore in more depth. As an example, a wetland story is provided that connects to the whakapapa elements entitled environmental transformations (Figure 6), kaitiakitanga and environmental sustainability (Figure 7). This wetland story is much more than a mere history also providing a commentary of relationships, power, aspirations and agency. These whakapapa sequences, therefore, provide a holistic and relational understanding of the phenomena of environmental management. An understanding that is not restricted to the grand narrative or the past as whakapapa is never-ending, dynamic, fluid and future-focused.

Understanding the past is critical for determining a future that is sustainable and equitable. Aotearoa New Zealand's environmental histories acknowledge a legacy of resource depletion and environmental degradation. It also, however, provides a pathway forward through the performance of kaitiakitanga and environmental sustainability; manaaki whenua, manaaki tangata, haere whakamua/our future depends on caring for the land and people.

Funding: This paper was developed as part of He Tātai Whenua, a Ministry of Business Innovation and Enterprise funded project that is developing a Māori landscape classification system.

Acknowledgments: I would also like to thank April Bennett and Meihana Durie for their feedback on early drafts and the two anonymous referees.

Conflicts of Interest: The author declares no conflict of interest.

\section{Glossary}

Aotearoa
hapū
Ira atua
Ira tangata
Kaitiakitanga
Kaupapa Māori research
Kōrero tuku iho
Mahi mara
Mahinga kai
mana
Māori
Mauri
Mātauranga Māori/mātauranga
Pūrākau
Te Tiriti o Waitangi
Te whare tapa whā
Te wheke
Tikanga
Rāhui
Waiata
Whakapapa
Whakataukī
Wharenui

Māori name for New Zealand

Subtribe

Ancestral life principle

Humanity

Māori environmental ethos and practices

Approach to research based on Māori worldview and political agenda

Genealogical narrative; narratives derived from whakapapa

Gardening

Collection of wild foods

Authority

Indigenous people of Aotearoa

Life force

Māori knowledge

Narratives

Treaty of Waitangi

Māori framework for conceptualising health based on the four-sided whare

Māori framework for conceptualising health based on the octopus

Actions

Restrictions to protect natural resources

Songs

genealogy

Sayings

Tribal meeting house 


\section{Names in Whakapapa Sequences (In Order of Appearance)}

\begin{tabular}{|c|c|}
\hline Te Ao Māori & The Māori world \\
\hline Te Ao Hurihuri & The changing world \\
\hline $\begin{array}{l}\text { Te Ao Tautohe } \\
\text { Figure } 2\end{array}$ & The contested world \\
\hline Te Kore & World of darkness \\
\hline Te Pō & World of potential \\
\hline $\begin{array}{l}\text { Te Ao Mārama } \\
\text { Figure } 3\end{array}$ & World of light \\
\hline Ranginui & Sky father \\
\hline Papatūānuku & Earth Mother \\
\hline Tangaroa & God of sea \\
\hline Punga & Son of Tangaroa \\
\hline Ikatere & Offspring of Punga; ancestor of the fish of the sea \\
\hline Tūtewehiwehi & Offspring of Punga; ancestor of the fish and lizards of inland waterways \\
\hline Tāne & God of the forest \\
\hline Te Ao Tūroa & The natural world \\
\hline $\begin{array}{l}\text { Kurawaka } \\
\text { Figure } 4\end{array}$ & Sacred place that held life principle of humanity \\
\hline Mana atua & Power derived from whakapapa \\
\hline Mana whenua & Power derived from ancestral landscapes \\
\hline Mana tangata & Power linked to upholding the dignity and wellbeing of people \\
\hline Tikanga tiaki & Guardianship customs \\
\hline
\end{tabular}

\section{References}

Awatere, Shaun, and Garth Harmsworth. 2014. Ngā Aroturukitanga Tika mō ngā Kaitiaki: Summary Review of Mātauranga Māori Frameworks, Approaches, and Culturally Appropriate Monitoring Tools for Management of Mahinga Kai. Hamilton: Manaaki Whenua Landcare Research.

Belgrave, Michael, Merata Kawharu, and David Williams. 2004. Waitangi Revisited: Perspectives on the Treaty of Waitangi. Auckland: Oxford University Press.

Best, Elsdon. 1976. Māori Agriculture. Wellington: Shearer, Government Printer.

Best, Elsdon. 1977a. Fishing Methods and Devices of the Māori. Wellington: Keating.

Best, Elsdon. 1977b. Forest Lore of the Māori. Wellington: Keating.

Bevir, Mark. 2010. Rethinking governmentality: Towards genealogies of governance. European Journal of Social Theory 13: 423-11. [CrossRef]

Boast, Richard. 1999. Māori Land Law. Wellington: Butterworths.

Carter, Lyn. 2019. Aotearoa/New Zealand adaptation strategies and practices. In Indigenous Pacific Approaches to Climate Change. Palgrave Studies in Disaster Anthropology. Cham: Palgrave Pivot, pp. 71-84.

Coombes, Brad, and Stephanie Hill. 2005. Fishing for the Land under Water-Catchment Management, Wetland Conservation and the Wairoa Coastal Lagoons. A Report Prepared for the Crown Forestry Rental Trust. Auckland: School of Geography and Environmental Science, University of Auckland.

Durie, Mason. 1994. Whaiora: Māori Health Development. Auckland: Oxford University Press.

Durie, Mason. 1998. Te Mana te Kāwanatanga: The Politics of Māori Self-Determination. Auckland: Oxford University Press.

Forster, Margaret. 2012. Hei Whenua Papatipu: Kaitiakitanga and the Politics of Enhancing the Mauri of Wetlands. Ph.D. thesis, Massey University, Palmerston North, New Zealand.

Forster, Margaret. 2013a. Imagining new futures: Kaitiakitanga and Agri-Foods. New Zealand Sociology 28: 9-32.

Forster, Margaret. 2013b. Kaitiakitanga as Environmental Leadership. In Ara Mai He Tetekura-Visioning Our Futures. New and Emerging Pathways of Maori Academic Leadership. Edited by Paul Whitinui, Marewa Glover and Daniel Hikuroa. Dunedin: Otago University Press, pp. 112-20.

Forster, Margaret. 2014. Indigeneity and trends in recognizing Māori environmental interests in Aotearoa New Zealand. Nationalism and Ethnic Politics 20: 63-78. [CrossRef]

Forster, Margaret. 2016. Indigenous environmental autonomy in Aotearoa New Zealand. AlterNative: An International Journal of Indigenous Scholarship 12: 316-30. [CrossRef] 
Grace, Wiremu. n.d. A Trilogy of Wahine Toa. Available online: http://eng.mataurangamaori.tki.org.nz/ Rauemitautoko/Te-Reo-Maori/Nga-Pakiwaitara-Maori-me-nga-Purakau-Onaianei/He-raupapa-toru-ongawahine-toa (accessed on 15 January 2019).

Graham, James. 2009a. Nā Rangi tāua, nā Tūānuku e takato nei: Research methodology framed by whakapapa. MAI Review 1: 3.

Graham, James. 2009b. Whakatangata Kia Kaha: Toitū te Whakapapa, Toitū te Tuakiri, Toitū te Mana. An Examination of the Contribution of Te Aute College to Māori Advancement. Unpublished Ph.D. dissertation, Massey University, Palmerston North, New Zealand. Available online: https://mro.massey.ac.nz/handle/ 10179/1254 (accessed on 19 March 2019).

Haami, Brad, and Mere Roberts. 2002. Genealogy as taxonomy. International Social Science Journal 54: 403-12. [CrossRef]

Harris, Aroha. 2004. Hikoi: Forty Years of Māori Protest. Wellington: Huia Publishers.

Hayward, Janine. 2003. Local Government and the Treaty of Waitangi. Victoria: Oxford University Press.

Hayward, Janine, and Nicola Wheen. 2004. The Waitangi Tribunal. Te Roopu Whakamana $i$ te Tiriti o Waitangi. Wellington: Bridget Williams Books.

Kawharu, Merata. 2000. Kaitiakitanga: A Māori anthropological perspective of the Māori socio-environmental ethic of resource management. Journal of the Polynesian Society 109: 349-70.

King, Darren, Wendy Shaw, Peter Meihana, and James Goff. 2018. Māori oral histories and the impact of tsunamis in Aotearoa New Zealand. Natural Hazards and Earth System Sciences 18: 907-19. [CrossRef]

McClean, Robert, and Trecia Smith. 2001. The Crown and Flora and Fauna: Legislation, Policies, and Practices, 1983-98. Wellington: Waitangi Tribunal.

Mead, Hirini Moko. 2003. Tikanga Māori: Living by Māori Values. Wellington: Huia Publishers.

Memon, Pyarali Ali. 1995. Keeping New Zealand Green. Recent Environmental Reforms; Wellington: Government Press.

Mikaere, Ani. 2003. The Balance Destroyed: Consequences for Māori Women of the Colonisation of Tikanga Māori. Auckland: The International Research Institute for Māori and Indigenous Education.

Morgan, Te Kipa Keepa. 2004. A Tangata Whenua Perspective on Sustainability Using the Mauri Model: Towards Decision-Making Balance with Regard to Our Social, Economic, Environmental and Cultural Well-Being. Paper presented at the International Conference on sustainability Engineering and Science, Auckland, New Zealand, July 6-9.

Pawson, Eric, and Tom Brooking. 2011. Seeds of Empire: The Environmental Transformation of New Zealand. London: I.B. Tauris.

Pawson, Eric, and Tom Brooking. 2013. Making a New Land: Environmental Histories of New Zealand. Dunedin: Otago University Press.

Pere, Rangimārie Rose. 1991. Te Wheke: A Celebration of Infinite Wisdom. Gisborne: Ao Ako Global Learning.

Petrie, Hazel. 2006. Chiefs of Industry: Māori Tribal Enterprise in Early Colonial New Zealand. Auckland: Auckland University Press.

Roberts, Mere, Waerete Norman, Nganeko Minhinnick, Dell Wihongi, and Carmen Kirkwood. 1995. Kaitiakitanga: Māori perspectives on conservation. Pacific Conservation Biology 2: 7-20. [CrossRef]

Rochford, Tim. 2004. Whare tapa wha: A Māori model of a unified theory of health. The Journal of Primary Prevention 25: 41-57. [CrossRef]

Rose, Nikalos, Pat O’Malley, and Mariana Valverde. 2006. Governmentality. Annual Review of Law Society 2: 83-104. [CrossRef]

Royal, Te Ahukaramū Charles. 1998. Te Ao Mārama: A research paradigm. He Pukenga Kōrero 4: 1-8.

Royal, Te Ahukaramū Charles. 2003. The Woven Universe: Selected Writings of the Rev. Māori Marsden. Ōtaki: Estate of Rev. Māori Marsden.

Royal, Te Ahukaramū Charles. 2005. Māori Creation Traditions. Te Ara-The Encyclopedia of Nerw Zealand. Available online: http://www.TeAra.govt.nz/en/maori-creation-traditions (accessed on 2 April 2019).

Royal, Te Ahukaramū Charles. 2007. Te Ao Mārama-The Natural World-An Interconnected World. Te Ara-The Encyclopedia of New Zealand. Available online: http://www.TeAra.govt.nz/en/te-ao-marama-the-naturalworld/page-2 (accessed on 11 January 2019).

Sadler, Hone. 2007. Mātauranga Māori (Māori Epistemology). International Journal of the Humanities 4: 33-45. [CrossRef] 
Smith, Linda Tuhiwai. 1999. Decolonizing Methodologies: Research and Indigenous Peoples. London: Zed Books, Dunedin: University of Otago Press.

Taonui, Rawiri. 2012. Māori urban protest movements. In Huia Histories of Māori: Nḡā Tāhuhu Korero. Edited by Danny Keenan. Wellington: Huia Publishers, pp. 230-59.

Tawhai, Veronica, and Katarina Gray-Sharp. 2011. 'Always Speaking': The Treaty of Waitangi and Public Policy. Wellington: Huia Publishers.

Taylor, Rowan. 1997. The State of New Zealand's Environment. Wellington: Ministry for the Environment, Manatū mō te Taiao, Wellington: GP Publications.

Te Rito, Joe. 2007. Te Tīhoka me te Karo: Struggles and Transformation of Ngāti Hinemanu of Ōmahu. Unpublished Ph.D. thesis, University of Auckland, Auckland, New Zealand.

Tipa, Gail, and Laurel D. Teirney. 2003. A Cultural Health Index for Streams and Waterways: Indicators for Recognising and Expressing Māori Values; Wellington: Ministry for the Environment.

Waitangi Tribunal. 2011. Ko Aotearoa Tènei. A Report into Claims Concerning New Zealand Law and Policy Affecting Māori Culture and Identity. Wellington: Legislation Direct.

Walker, Ranginui. 1984. The genesis of Māori activism. Journal of the Polynesian Society 93: 267-82.

Walker, Ranginui. 1990. Ka Whawhai Tonu Matou: Struggle without End. Auckland: Penguin Books.

Warren, Te Rina, Margaret Forster, and Veronica Tawhai. 2017. Tangata whenua: Māori identity and belonging. In Türangawaewae: Identity and Belonging in Aotearoa New Zealand. Edited by Trudie Cain, Ella Kahu and Richard Shaw. Auckland: Massey University Press, pp. 53-69.

Young, David. 2004. Our Islands, Our Selves. Dunedin: University of Otago Press.

(C) 2019 by the author. Licensee MDPI, Basel, Switzerland. This article is an open access article distributed under the terms and conditions of the Creative Commons Attribution (CC BY) license (http://creativecommons.org/licenses/by/4.0/). 